\title{
Investigating the effective factors on management internal controls applying
}

\author{
Reza Pirayesh $^{\mathrm{a}}$, Roghieh Niazi ${ }^{\mathrm{b}}$ and Ahmad Ahmadkhani ${ }^{*}$
}

${ }^{a}$ Department of Management and Accounting, Zanjan University, Zanjan, Iran

${ }^{b}$ Department of Management, Islamic Azad University, Qazvin Branch, Qazvin, Iran

${ }^{c}$ Sama Technical Vocational Training College, Islamic Azad University, Zanjan, Iran

\section{A R T I C L E I N F O}

Article history:

Received October 1, 2011

Received in Revised form

November, 14, 2011

Accepted 15 February 2012

Available online

28 February 2012

Keywords:

Internal control

Information technology

Management internal controls

Accounting

\section{A B S T R A C T}

\begin{abstract}
Information technology plays an important role on increasing internal control in many organizations. In this paper, we present an empirical study to measure the impact of information technology, hiring high quality skilled management team, using high quality standards and increasing employees' awareness on managing internal control. The survey uses a questionnaire based on Likert scale and distributes among the people who work in either administration or financial sectors of governmental agencies in province of Zanjan, Iran. The results of the study indicate that the implementation of information technology positively influences management team to control their system, more effectively, using more skilled and specialized managers positively influences management internal control, an organization with suitable standard positively influences management internal control and increasing employees' awareness positively influences management internal control.
\end{abstract}

(C) 2012 Growing Science Ltd. All rights reserved.

\section{Introduction}

Information technology has become a necessity in today's business enterprises. Information technology can increase profitability through reducing the cost of operation, significantly. There are literally many studies associated with the implementation of information technology in different accounting programs.

Doyle et al. (2007) studied the weaknesses in internal control over financial reporting. They examined the weaknesses in internal control for 779 firms and revealed material weaknesses from August 2002 to 2005. They reported that these firms tend to be smaller, more complex, growing rapidly, younger, financially weaker, or undergoing restructuring. According to their survey, business units with more serious entity-wide control problems were smaller, younger and weaker financially, while firms with less severe, account-specific problems were healthy financially but had diversified,

\footnotetext{
* Corresponding author. Tel. + 09127413789

E-mail addresses: rogiehniazy@yahoo.com (R. Niazy) 
complex and rapidly changing operations. They also reported that the determinants also vary depending on the particular reason for the material weakness, consistent with each firm facing their own unique set of internal control challenges.

Ashbaugh-Skaife et al. (2007) used internal control deficiency (ICD) disclosures prior to mandated internal control audits to study economic factors, which expose firms to control failures and managements' incentives to find out control problems. They reported that, relative to non-disclosers, firms disclosing ICDs had recent organizational changes, more complex operations, greater accounting risk, more auditor resignations and had fewer resources available for internal control. Regarding incentives to locate internal control problems, ICD firms seem to have more prior SEC enforcement actions and financial restatements.

Li et al. (2006) built a conceptual technique to explain the relationship among internal control systems, firm orientation and new product development, and to examine empirically how market influence the degree of improvement in new product development through personal and/or output control in the Chinese transitional economy. They reported that entrepreneurship orientation not only positively impact on the degree of improvement in new product development, but also indirectly has a positive influence on it through personal control. They also reported that market orientation, through output control, had a negative indirect influence.

Leone et al. (2007) investigated two studies on ICD and reported that both control risk factors associated with organizational complexity and significant organizational change, as well as relative investment in internal control systems, were related to disclosure of internal control. He presented alternative explanations and provided some descriptive evidence, which was consistent with these alternative explanations.

Shapiro and Matson (2008) implemented the institutional concepts of resource dependence, resistance, power and dramaturgical exchange to the legislative regulation of the Foreign Corrupt Practices Act (FCPA) of 1977, internal control regulations and proposals from the late 1970s to the late 1990s, and the internal control needs under the Sarbanes-Oxley Act (SOX) of 2002. The analysis revealed that from 1976 to 2001 powerful organizations and individuals employed active strategies of avoidance, defiance, and manipulation to successfully defeat proposals, which would have required all public companies to assess and report on their internal controls over financial reporting, publicly.

At that time, the US Securities and Exchange Commission (SEC) vacillated between actively defending mandatory internal control reporting and passively acquiescing to industry and White House requested for voluntary internal control reporting. They considered how the ongoing dramaturgical exchange between regulators and regulatees could substantially weaken the internal control requirements of SOX (2002).

Pierce and Sweeney (2005) suggested the existence of previously unidentified controls at partner level, which is in the procedures and routines through which potential cost-quality conflicts were managed. The study explains the relative importance of these controls in achieving a balance between trust-building and additional monitoring.

Altamuro and Beatty (2010) investigated on how internal control regulation influence financial reporting. They presented a difference-in-differences method, which suggested that Federal Depository Insurance Corporation Improvement Act mandated internal control requirements increased loan-loss provision validity, earnings persistence and cash-flow predictability and reduced benchmark-beating and accounting conservatism for affected versus unaffected banks. More pronounced effects in interim versus fourth quarters suggest that greater auditor presence substitutes for internal control regulation. 
Gulamhussen and Guerreiro (2009) investigated the impact of foreign equity and board membership on firm strategy and internal cost management in Portuguese banks using proprietary data provided by the Central Bank. Their results indicated that foreign equity reduces both total and operating costs. They also argued that foreign equity and board membership forces banks to redirect corporate strategy and to reduce internal costs.

In this paper, we present an empirical study to measure the impact of information technology, hiring high quality skilled management team, using high quality standards and increasing employees' awareness on managing internal control. The organization of this paper first presents details of our hypothesis in section 2 and section 3 presents details of our finding. The paper ends with concluding remarks in section 4 .

\section{The proposed study}

There are four hypothesis associated with the proposed study of this paper, which are as follows,

H1: The implementation of information technology could help management team control their system, more effectively.

H2: Using more skilled and specialized managers positively influences management internal control.

H3: An organization with suitable standard positively influences management internal control.

H4: Increasing employees' awareness positively influences management internal control.

The proposed study of this paper uses a questionnaire consists of 21 questions, which are associated with internal control management. All questions are designed in Likert scale from one to five. The questionnaires are distributed among 20 people and Cronbach Alpha has been calculated as 0.88, which is well above the minimum desirable level of 0.70 .

Feng et al. (2009) examined the relationship between internal control quality and the accuracy of management guidance. In their study, they document less accurate guidance among firms providing ineffective internal controls. They reported that internal control quality had an economically significant influence on internal management reports and thus decisions based on these figures could improve the performance of the organizations, significantly.

Sandelin (2008) in an empirical case study investigated the operation of management control practices as a tool in a growth firm context by couplings among cultural, personnel, action and results controls. The study concentrated on two various management control tools in the face of similar contingencies at different points of time. They argued that the functionality of a control package depends on internal consistency, specifically on the reciprocal relationship of design and implementation between a primary mode of control and other control components. The results also argue that control package variety could be driven on how management responds to functional demands.

The questions have been tested using SPSS software package and the data are analyzed using nonparametric binomial test, t-student and Freedman tests. We use the following formula to calculate the minimum number of sample size,

$n=\frac{N \times z_{\alpha / 2}^{2} \times p \times q}{\varepsilon^{2} \times(N-1)+z_{\alpha / 2}^{2} \times p \times q}$,

where $N$ is the population size, $p=1-q$ represents the yes/no categories, $z_{\alpha / 2}$ is CDF of normal distribution and finally $\varepsilon$ is the error term. Since we have $p=0.5, z_{\alpha / 2}=1.96$ and $N=195$, the number 
of sample size is calculated as $n=149$. The population considers all employees who work in adminstration and finacial sectors of governmental agencies.

\section{The results}

Table 1 shows details of our survey for four hypothesis associated based on binomial test and tstudents

Table 1

The results of binomial test and t-student

\begin{tabular}{lllllllll}
\hline & Group & Mean & \# of observations & ratio & Base & P-value & Mean & Result \\
\hline \multirow{2}{*}{ H1 } & Agree & $>=3$ & 0 & 0 & & & & \\
& Disagree & $<3$ & 149 & 1 & 0.50 & 0.000 & 4.55 & Confirmed \\
& Total & & 149 & 1 & & & & \\
\hline \multirow{2}{*}{ H2 } & Agree & $>=3$ & 0 & 0 & & & & \\
& Disagree & $<3$ & 148 & 1 & 0.50 & 0.000 & 4.33 & Confirmed \\
& Total & & 148 & 1 & & & & \\
\hline \multirow{3}{*}{ H3 } & Agree & $>=3$ & 0 & 0 & & & & \\
& Disagree & $<3$ & 148 & 1 & 0.50 & 0.000 & 4.29 & Confirmed \\
& Total & & 148 & 1 & & & & \\
\hline \multirow{2}{*}{ H4 } & Agree & $>=3$ & 2 & 0.01 & & & & \\
& Disagree & $<3$ & 146 & 0.99 & 0.50 & 0.000 & 4.16 & Confirmed \\
& Total & & 148 & 1 & & & & \\
\hline
\end{tabular}

As we can observe from the results of Table 1, all hypothesis have been confirmed. Therefore, we can conclude that the implementation of information technology positively influences management team to control their system, more effectively, using more skilled and specialized managers positively influences management internal control, an organization with suitable standard positively influences management internal control and increasing employees' awareness positively influences management internal control.

We have also implemented Freedman test to rank four hypothesis based on their relative importance. Table 2 shows details of the implementation of this test.

Test 2

Freedman ranking test results

\begin{tabular}{lll}
\hline Hypotheses & Mean rank & Rank \\
\hline H1: Using an appropriate information technology & 3.22 & 1 \\
H2: Hiring skillful management team & 2.42 & 2 \\
H3: Implementing high quality standards & 2.36 & 3 \\
H4: Increasing employees' awareness & 2.00 & 4 \\
\hline
\end{tabular}

As we can observe from the results of Freedman test, the implementation of information technology is the most important item, which could influence management internal control followed by hiring high skilled management team. In addition, we may increase the quality of internal controls by posing high quality standards as well as increasing employees' awareness.

The results of our survey indicate that timely information using appropriate software packages could significantly help management team make better managerial decisions. It is highly recommended that management team have university background. In addition, a transparent rules and regulations help management team better control the system. Finally, the survey suggests good responsibility 
assignments to employees, which is believed to highly influence the internal control but there is a little impact on using employee feedback system on internal control.

\section{Conclusion}

In this paper, we have presented an empirical study to measure the impact of information technology, hiring high quality skilled management team, using high quality standards and increasing employees' awareness on managing internal control. The survey used questionnaire based on Likert scale and distributed among the people who work in either administration or financial sectors of governmental agencies in province of Zanjan, Iran.

The results of the study indicated that the implementation of information technology positively influences management team to control their system, more effectively, using more skilled and specialized managers positively influences management internal control, an organization with suitable standard positively influences management internal control and increasing employees' awareness positively influences management internal control.

Based on the results of this survey, we can suggest that it is possible to improve management internal control by using integrated information technology. There must be unique supervision on input/output data so that management could easily monitor the flow of data. One important point is increase the level of security in the data. The other important point is to provide good training system so that employees feel comfortable on using the information technology systems. Management plays essential role on the success of a firm and any attempt on hiring high quality people could help firm succeed.

\section{Acknowledgment}

The authors would like to thank the anonymous referees for constructive comments on earlier version of this work.

\section{References}

Altamuro, J., \& Beatty, A. (2010). How does internal control regulation affect financial reporting?. Journal of Accounting and Economics, 49(1-2), 58-74.

Ashbaugh-Skaife, H., Collins, D.W., \& Kinney Jr., W.R. (2007). The discovery and reporting of internal control deficiencies prior to SOX-mandated audits. Journal of Accounting and Economics, 44(1-2), 166-192.

Cronbach, L. J. (1951). Coefficient alpha and the internal structure of tests. Psychometrika, 16(3), 297-334.

Doyle, J., Ge, W., \& McVay, S. (2007). Determinants of weaknesses in internal control over financial reporting. Journal of Accounting and Economics, 44(1-2), 193-223.

Feng, M., Li, C., \& McVay, S. (2009). Internal control and management guidance. Journal of Accounting and Economics, 48(2-3), 190-209.

Gulamhussen, M.A., \& Guerreiro, L. (2009).The influence of foreign equity and board membership on corporate strategy and internal cost management in Portuguese banks. Management Accounting Research, 20(1), 6-17.

Leone, A. J. (2007). Factors related to internal control disclosure: A discussion of Ashbaugh, Collins, and Kinney (2007) and Doyle, Ge, and McVay (2007). Journal of Accounting and Economics, 44(1-2), 224-237. 
Li, Y., Liu, Y., \& Zhao, Y. (2006). The role of market and entrepreneurship orientation and internal control in the new product development activities of Chinese firms. Industrial Marketing Management, 35(3), 336-347.

Likert, R. (1932). A Technique for the Measurement of Attitudes. Archives of Psychology, 140, 1-55.

Shapiro, B., \& Matson, D. (2008). Strategies of resistance to internal control regulation. Accounting, Organizations and Society, 33(2-3), 199-228.

Sandelin, M. (2008). Operation of management control practices as a package-A case study on control system variety in a growth firm context. Management Accounting Research, 19(4), 324343.

Pierce, B., \& Sweeney, B. (2005). Management control in audit firms-Partners' perspectives. Management Accounting Research, 16(3), 340-370. 